
МЕТОДИКА НАВЧАННЯ ДІТЕЙ 5-7 РОКІВ ДИХАЛЬНИХ ВПРАВ
У ПРОЦЕСІ ПРАКТИКИ ХАТХА-ЙОГИ

\title{
METHODOLOGY OF TEACHING OF 5-7 YEARS OLD CHILDREN OF BREATHING EXERCISES IN THE PROCESS OF HATHA YOGA PRACTICE
}

\begin{abstract}
Метою статті є опис розробленої автором методики навчання дітей 5-7 років дихальних вправ у процесі практики хатха-йоги. Дихальна гімнастика є могутнім чинником оздоровчої дії на організм. Активні заняття дихальними вправами ведуть до оптимізаціі стану співвідношення процесів збудження і гальмування в чентральній нервовій системі, сприяють усуненню фуннкіональних порушень з ї сторони. У дитячому віці закладається фундамент здоров'я, починають розвиватися різноманітні здібності, формуються моральні якості, складаються риси характеру. Від того, як виховується дитина в чі роки, багато в чому залежить ії майбутнє, ефективність шкільного навчання, майбутне формування особистості. Такі дихальні вправи з хатха-йоги, як Повне дихання йогів, Очисне дихання та Кумбхака (короткочасні затримки), мають на меті формування навичок правильного дихання, підвищення функціональних можливостей системи зовнішнього дихання й організму в цілому, зниження захворюваності, а також поліпшення процесів мови і мислення. Розроблена автором методика навчання дітей 5-7 років дихальних вправ у процесі практики хатха-йоги передбачає використання найбільш ефективних вихідних положень, зосередження свідомості на певному енергетичному чентрі (чакрі), виконання дихальних вправ за фрізіологічно оптимальною та безпечною технікою. Це сприятиме повноцінному та безпечному оволодінню дітьми таких дихальних вправ, як Повне дихання йогів, Очисне дихання та Кумбхака (короткочасні затримки). Оволодіння переліченими дихальними вправами є одним із фрундаментальних положень успішної практики хатхайоги. Дія запропонованих технік дихання обгрунтована теоретично та підтверджена практичним досвідом. Авторська методика навчання дітей 5-7 років дихальних вправ у процесі практики хатха-йоги може бути використана як на заняттях $з$ хатха-йоги, так і у дошкільних та загальноосвітніх навчальних закладах.

Ключові слова: хатха-йога, дихальна гім-
\end{abstract} настика, методика навчання, дитячий вік, заняття з дітьми, практика хатха-йоги з дітьми.

The purpose of the article is to describe the method of teaching 5-7 years old children the breathing exercises during the practice of Hatha yoga developed by the author. Respiratory gymnastics is a powerful factor in the wellbeing of the body. Active breathing exercises lead to optimization of the state of the ratio of excitation and inhibition processes in the central nervous system, contribute to the elimination of functional disorders on its part. In childhood the foundations of health are laid, various abilities begin to develop, moral qualities are formed, character traits are formed. The future of the child, the effectiveness of school education, and the further formation of personality largely depend on how the child is raised during these years. Hatha Yoga Breathing Exercises such as Full Yoga Breathing, Purified Breathing, and Kumbhaka (short-term delays) aim to form proper breathing skills, enhance the functionality of the external breathing system and the body as a whole, and reduce morbidity, as well as disease, and thinking. Developed by the author the method of teaching 5-7 years old children the breathing exercises in the practice of Hatha yoga involves the use of the most effective starting points, concentration of consciousness on a particular energy center (chakra), performing breathing exercises on physiologically optimal and safe technique. This will help children to fully and safely master breathing exercises such as Full Yoga Breathing, Purification Breathing, and Kumbhaka (short-term delays). Mastering these breathing exercises is one of the fundamental principles of successful Hatha yoga practice. The effect of the proposed breathing techniques is theoretically substantiated and proven by practical experience. The author's method of teaching 5-7 years old children the breathing exercises in the practice of Hatha yoga can be used both in Hatha yoga classes, as well as in preschool and general educational institutions.

Key words: Hatha yoga, breathing exercises, teaching methods, childhood, lessons with children, practice of Hatha yoga with children.

Дитячий вік за умови дотримання найбільш

Постановка проблеми у загальному вигляді. Дихальна гімнастика $€$ могутнім чинником оздоровчої дії на організм. Активні заняття дихальними вправами ведуть до оптимізації стану співвідношення процесів збудження і гальмування в центральній нервовій системі, сприяють усуненню функціональних порушень 3 її сторони. Все це разом з постановкою правильного дихання покращує екскурсію грудної клітини та укріплює дихальні м'язи, сприяє усуненню порушень у сфері нейроендокринної регуляції, зниженню підвищеної лабільності бронхів, відновленню нормального механізму дихання, нормалізації діяльності інших внутрішніх органів [3]. оптимальної методики навчання дітей техніки виконання дихальних вправ є сприятливою умовою для фрормування навичок правильного дихання, підвищення функціональних можливостей системи зовнішнього дихання й організму в цілому, зниження захворюваності, а також поліпшення процесів мови і мислення. У цей період закладається фундамент здоров'я, починають розвиватися різноманітні здібності, фформуються моральні якості, складаються риси характеру. Від того, як виховується дитина в ці роки, багато в чому залежить її майбутнє, ефективність шкільного навчання, майбутнє фрормування особистості. 
Аналіз останніх досліджень і публікацій. Велика увага у практиці хатха-йоги приділяється техніці дихання. Низка авторів відзначають важливість застосування дихальних вправ у фрізичному вихованні дітей для фрормування навичок правильного дихання, підвищення функціональних можливостей системи зовнішнього дихання й організму загалом, зниження захворюваності, а також поліпшення процесів мови і мислення [2; 6]. Висока ефективність адаптованих для дитячого організму систематичних занять 3 хатха-йоги зумовлена, крім перерахованого, ще й її здатністю відновлювати захисні системи організму, нормалізувати роботу нервової, дихальної, серцево-судинної та ендокринної систем [1; 4; 5].

Виділення не вирішених раніше частин загальної проблеми. У сучасних наукових дослідженнях наведені рекомендації щодо застосування дихальних вправ. Усі вони ґрунтуються на правилах дихання хатха-йоги. Проте відсутні методичні рекомендації з навчання дітей старшого дошкільного та молодшого шкільного віку дихальних вправ у процесі практики хатха-йоги.

Мета статті. Метою статті $€$ опис розробленої автором методики навчання дітей 5-7 років дихальних вправ у процесі практики хатха-йоги.

Виклад основного матеріалу. Спочатку необхідно якомога більше позитивного розповідати дітям про дихання, дихальну систему. Правильне дихання дуже важливе для людини. Дихання - це життя, це вентиляція тіла. Дихання робить людину або хворою, або здоровою. Все на Землі дихає: і рослини, і тварини, і птахи, і земля. Розкажіть дітям, що кожній клітині організму потрібне повітря для життя.

Дітям 5-6 років давати багато дихальних вправ немає необхідності, оскільки головне у практиці хатха-йоги - це любов до себе та задоволення від занять. Слід розповісти дітям про легені, їхні анатомо-фрізіологічні особливості. Доцільним буде обговорювання таких питань: «Чому, якщо надовго затримати подих, то обов'язково хочеться дихати?», «Чому, коли часто дихаєш, починає крутитися голова?», «Що таке вдих і видих?».

Під час опанування дихальних вправ 3 дітьми 5-7 років слід зупинитися на трьох основних дихальних вправах (техніка виконання вправ буде детальніше описана нижче):

1. Повне дихання йогів. Нехай діти уявляють, що всередині у них знаходиться довга повітряна кулька. Вони починають надувати її знизу, з живота, після надувають там, де груди, а потім де шия. Потім кульку розв'язують і вона здувається знизу, в грудях і вище грудей. Буде більш ефективним заняття, якщо діти будуть уявляти кульку такого кольору, якого кольору енергетичний центр (чакра). Це жовтий (третя чакра, живіт), смарагдово-зелений (четверта чакра, ділянка серця, грудна клітина), блакитний (п'ята чакра, ділянка від шиї до брів).

2. Очисне дихання. Нехай діти у положенні стоячи уявляють, що вони великий паровоз. Він наближається до станції, і машиніст дає гудок. Все тіло напружене і проводиться очисний подих невеликими порціями крізь губи.

3. Кумбхака (короткочасні затримки). Нехай діти уявляють, що вони надули кульку і тепер не спускають її і при цьому милуються ії красою, кольором і повільно видихають.

Техніка виконання різних дихальних вправ.

Дуже багато дихальних вправ (пранаям) виконуються в положенні сидячи. У йозі є досить багато «сидячих» поз, але основних чотири: Сукха-сану, Сіддхасана, Ардхпадмасана і Падмасана. Нижче наведено опис цих поз.

Пози для сидіння

1. Сукхасана (сидячи по-турецьки) (легка поза).

У цій позі важливо тримати голову, шию і тулуб без відхилень від прямої лінії - натягнута струна.

Ця поза використовується в тому разі, якщо не вистачає гнучкості для того, щоб сидіти в лотосі або напівлотосі, для медитацій, споглядання, дихальних вправ.

2. Сіддхасана (поза знавця).

Вихідне положення - сісти прямо, з витягнутим угору хребтом.

Техніка виконання - зігнувши ліву ногу, покласти її підошву так, щоб вона п'ятою впиралася в промежину. Стопу правої ноги покласти зверху на ступню лівої так, щоб не відчувалося ніяких незручностей. Стежити, щоб хребет перебував у вертикальному положенні. Перебувати у цій асані можна від кількох секунд до кількох десятків хвилин. Періодично змінювати положення ніг (інша нога зверху).

Ефект. Сіддхасана вважається однією з найважливіших асан. Вона дуже благотворно діє на нервову систему, покращує кровопостачання в ділянці таза, відновлює рівновагу багатьох фрізіологічних процесів в організмі.

3. Ардхападмасана (напівлотос).

Вихідне положення - сидячи прямо з витягнутим угору хребтом.

Техніка виконання - ступні ніг лежать вільно: верхня на стегні протилежної ноги, нижня під стегном. Стежити, щоб хребет перебував у вертикальному положенні. Час перебування у положенні (асані) необмежений. Періодично змінювати положення ніг (інша нога зверху)

4. Падмасана (поза лотоса).

Вихідне положення - сидячи прямо з витягнутим угору хребтом.

Техніка виконання - згинаючи праву ногу в коліні, взяти руками стопу і покласти їі на ліве стегно, вивертаючи підошву вгору. Праве коліно притиснути до підлоги. Потім зігнути ліву ногу 
в коліні, взяти стопу і покласти її на праве стегно, також вивертаючи підошву вгору. Тримати спину, голову і шию прямими. Час перебування в асані необмежений.

Освоювати Падмасану (позу лотоса) потрібно дуже обережно. Зазвичай на її освоєння йде від декількох тижнів до декількох місяців.

Ефект. Це одна 3 основних асан у йозі. Чинить різнобічну дію. Заспокоюються нервова система, внутрішні органи, відновлюється динамічна рівновага всіх сил організму. Зникає скутість у колінах і щиколотках, зміцнюється спина.

Вважається найоптимальнішою позою для медитації. Приводить організм в енергетичну рівновагу.

Повне дихання йогів сидячи

Вихідне положення - сидячи у Сіддхасані (позі знавця), Падмасані (позі лотоса), Ардхападмасані (позі полулотоса) або у Сукхасані (сидячи по-турецьки). Кисті розташовані на колінах, пальці рук у Джняні-мудрі (подушечки вказівних пальців обох рук з'єднані з подушечками великих, утворюють кільце; мізинець, безіменний і середній пальці залишаються випрямленими; долоня розгорнута вгору). Спина пряма.

Техніка виконання - виконати чотирнадцять повних дихальних циклів, при цьому свідомість направляти на різні ділянки тіла. Всього таких ділянок сім: область верхівки, область міжбрів'я, область щитовидної залози, область серця посередині грудної клітини на рівні серця, область пупа і сонячного сплетення, область лобкової кістки, область промежини. Спочатку виконують два повні дихання, концентруючи свідомість на області верхівки, потім два дихання з концентрацією свідомості на області міжбрів'я і так далі.

Повне дихання йогів здійснюється за рахунок послідовного виконання трьох фраз дихання: діафррагмального (черевного), грудного і ключичного.

Діафрагмальне (черевне) дихання здійснюється за рахунок скорочення черевних м'язів: на вдиху живіт злегка випинається, на видиху - втягується. Все це робиться плавно, без ривків.

Бажано спробувати практикувати це дихання не тільки сидячи, але і стоячи і лежачи. Для того щоб рухався тільки живіт, можна одну руку покласти на область лобка і стежити, щоб усе, що нижче рівня пупа, було нерухомим, а другу руку покласти на середину грудей на рівні серця і також стежити, щоб усе, що вище живота, залишалося нерухомим. Увагу чоловіки концентрують на область пупа, а жінки - на область серця (посередині грудної клітини). Намагатися, щоб час видиху дорівнював часу вдиху, а дихання було плавним, без ривків. Під час діафрагмального (черевного) дихання повітрям наповнюються нижні альвеоли легень.

Грудне дихання здійснюється за рахунок розширення грудної клітини під час вдиху й опадання ії̈ на видиху. Під час його освоєння також для контролю руху грудної клітини можна використовувати руки. Так само, як і у разі нижнього дихання, необхідно стежити, щоб час вдиху був рівний видиху, а подих здійснювався плавно, без ривків. Під час середнього дихання повітрям наповнюються альвеоли середньої частини легень.

Ключичне дихання виконується за рахунок підйому (на вдиху) і опускання (на видиху) верхньої частини грудної клітини (область ключиць). Під час верхнього дихання повітрям наповнюються альвеоли верхньої частини легень.

Повне дихання йогів здійснюється у такій послідовності: виконати максимально можливий повний видих для видалення з легень застояного повітря. Із вдихом випнути живіт і заповнити повітрям нижню частину легень, плавно розширивши грудну клітину, наповнити повітрям середню частину легень, злегка підвести плечі і заповнити повітрям верхівки легень. Не докладати зусилля наприкінці вдиху. 3 видихом втягнути живіт, опустити грудну клітину, опустити плечі.

Протягом вдиху і видиху м'язи живота нижче пупа підтягнуті і в диханні участі не беруть. Працюють тільки м'язи живота вище пупа, які безпосередньо впливають на діафррагму. Дихання має бути дуже плавним і рівномірним, без напруги і надмірного зусилля. Перехід від однієї фрази дихання до іншої здійснюється без зупинок і ривків.

Свідомість зосереджена у чоловіків на області пупа і сонячного сплетення, у жінок - на області серця.

У людей зі зниженим артеріальним тиском і у людей, у яких переважає ключичне дихання, іноді під час освоєння повного дихання йогів спостерігається запаморочення. Пояснюється це відтоком венозної крові від головного мозку, що $€$ корисним. Знімається відчуття запаморочення за допомогою асани Віпаріта Карані (поза стіни) або можна просто підняти ноги, лежачи на спині.

Повне дихання йогів стоячи.

Складається 3 трьох послідовно виконуваних варіантів:

1) стоячи на лівій нозі (чоловіки, жінки виконують навпаки);

2) стоячи на правій нозі;

3) стоячи на двох ногах.

Вихідне положення - зігнути вільну ногу в колінному суглобі і встановити п'ятою в пах.

Руки у всіх трьох варіантах у Намасті (долоня притиснута до долоні, великі пальці рук знаходяться у яремній ямці, вказівні - на відстані 2-3 міліметрів від підборіддя, середні пальці на рівні кінчика носа).

Техніка виконання - у будь-якому вигляді виконати по 7 повних дихальних циклів на сім областей, по одному подиху на кожну ділянку тіла (область верхівки, область міжбрів'я, область щитовид- 
ної залози, область серця - посередині грудної клітини на рівні серця, область пупа і сонячного сплетення, область лобкової кістки, область промежини). Техніка виконання, аналогічна техніці повного дихання йогів сидячи.

Есрект. У механізмі повного дихання беруть участь як міжреберні м'язи, так і один з найважливіших м'язів нашого тіла - діафрагма. Стискаючи кровоносні і лімфатичні судини живота, діасррагма спорожняє його венозну систему і проштовхує кров до грудної клітини. Число рухів діафррагми за хвилину становить приблизно чверть числа скорочень серця. Але її гемодинамічний напір набагато сильніший, ніж серцеві скорочення.

Уповільнене повне дихання йогів (не частіше чотирьох дихальних циклів за хвилину) із затримкою після вдиху, через зменшення тиску повітря в грудній клітині, полегшує приплив венозної крові до серця. Крім того, накопичення в організмі вуглекислого газу, що відбувається у разі уповільнення дихання, веде до розширення серцевих судин і, як наслідок, покращує живлення серцевого м'яза.

Повне дихання йогів чинить різнобічну дію на організм людини. Органи дихання зміцнюються і стають здоровими, зростає життєва ємність легень. Нормалізується артеріальний тиск, поліпшується діяльність серця, підвищується опірність усім хворобам. Нервова система приходить у рівновагу, організм звільняється від токсинів, поліпшується загальний стан людини, підвищується настрій.

Очисне дихання

Вихідне положення - виконується у положенні стоячи або сидячи, у будь-який час доби.

Техніка виконання. Очисне дихання виконується таким чином:

- зробити повний вдих;

- на затримці вдиху витягнути і скласти губи в шпаринку;

- зробити різкі видихи (декількома порціями) через відкриті губи так, щоб щоки не роздувати:

- під час виконання порційного видиху працює діафррагма, вся грудна клітина напружена.

Свідомість зосереджена у чоловіків на області пупа і сонячного сплетення, у жінок - на області серця.

Очисне дихання застосовується для очищення енергетичного поля від різного роду «брудних» емоційних енергій. Усі емоції, якщо вони неконтрольовані і надмірні, завдають серйозної шкоди нашому організму. Очищенню організму від подібного роду енергій і сприяє пропоноване нижче очисне дихання. Особливо корисно після різного роду емоційних консрліктів, стресових ситуацій. Також використовується для відновлення природного дихання після тривалих затримок дихання, бігу чи після напружених асан і пранаям, а також для зняття будь-якої втоми. Воно освіжає і дає відчуття бадьорості.
Кумбхака (короткочасні затримки).

Вихідне положення - сидячи у Падмасані (поза лотоса) або у Ардхападмасана (напівлотос). Спина пряма, кисті на колінах.

Техніка виконання - виконати повний вдих. Скоротити м'язи промежини, втягнути живіт, підборіддя опустити до грудей і злегка нахилити голову назад. Затримка на вдиху до дискомфорту. Виконати повний видих, поступово розслабляючи м'язи промежини і живота, підняти голову. Горло не віджимати. Час видиху дорівнює часу вдиху. Наприкінці вправи слід виконати очисне дихання.

Виконувати три рази.

Свідомість зосереджена на області серця.

Ефект. Вважається, що під час затримки дихання встановлюється рівновага між позитивними і негативними струмами, що забезпечують життя фрізичного та енергетичного тіла. Під час затримки дихання очищаються всі легеневі пухирці, що сприяє підвищенню їх активності. Крім того, ця вправа сприяє видаленню продуктів розпаду з крові.

Висновки. Таким чином, застосування розробленої автором методики навчання дітей 5-7 років дихальних вправ у процесі практики хатха-йоги, у якій передбачено використання найбільш ефрективних вихідних положень, зосередження свідомості на певному енергетичному центрі (чакрі), виконання дихальних вправ за фрізіологічно оптимальною та безпечною технікою, сприятиме повноцінному та безпечному оволодінню дітьми таких дихальних вправ, як Повне дихання йогів, Очисне дихання та Кумбхака (короткочасні затримки). Оволодіння переліченими дихальними вправами $є$ одним із фрундаментальних положень успішної практики хатха-йоги. Дія запропонованих технік дихання обґрунтована теоретично та підтверджена практичним досвідом. Авторська методика навчання дітей 5-7 років дихальних вправ у процесі практики хатха-йоги може бути використана як на заняттях $з$ хатха-йоги, так і у дошкільних та загальноосвітніх навчальних закладах.

\section{БІБЛІОГРАФІЧНИЙ СПИСОК:}

1. Бокатов А.И., Сергеев С.А. Детская йога. Киев : Ника-Центр, 1998. 352 с.

2. Вільчковський Е.С., Курок О.І. Теорія і методика фізичного виховання дітей дошкільного віку : навчальний посібник. Суми : ВТД «Університетська книга», 2008. 428 с.

3. Дикий Б.В. Застосування індійської гімнастики хатха-йоги у фізичній реабілітації та ЛФК : методичні рекомендації. Ужгород, 2013. 89 с.

4. Каминоффф Л. Анатомия йоги / пер. с англ. С.Э. Борич. 2-е изд. Минск : Попури, 2015. 240 с.

5. Коултер Д. Анатомия хатха-йоги. Москва : Сосия, 2015. 407 с.

6. Матвеев А.П. Методика фризического воспитания в начальной школе : учебное пособие для студентов средних специальных учебных заведений. Москва : ВЛАДОС-ПРЕСС, 2003. 248 с. 